\title{
Venice 1994
}

\author{
By Ron Holloway
}

Spring 1995 Issue of KINEMA

\section{VENICE 1994: ERMANNO OLIM'S GENESIS}

As befits a master filmmaker, Ermanno Olmi is reluctant to give interviews. He lets his films speak for themselves. A shy, self-effacing man, it's always been that way with Olmi. He was especially sparse on words when awarded the Golden Lion at the 1988 Venice festival for The Legend of a Holy Drinker and the Golden Palm at the 1978 Cannes festival for The Tree of Wooden Clogs. And there hasn't been a published interview with Olmi in nearly a decade.

One reason for the reticence is the embarrassment of having to answer those all too frequent, nagging "how are you?" and "what have you been doing?" questions. For between the Cannes premieres of The Tree of Wooden Clogs (1978) and Cammina Cammina (1983) lay five years of inactivity, then another four years until Long Live the Lady (Lunga vita à la signora, 1987) won the Silver Lion at Venice (to be followed a year later by the Golden Lion). During much of this time, he had been wrestling with a long and sometimes paralyzing illness.

So when Lux, the producers of The Bible, approached Olmi about giving an interview at Venice for the festival premiere of Genesis: Creation and Flood, his feature-length episode in the series made for Raiuno and Lube-Beta Film, he consented -- but on his own conditions. The interview was to be nothing more than a sit-down "talk" with a select group of journalists.

The site for the meeting was the Ai Frati working-man's restaurant on the pier of Murano island, a few doors down from the legendary glass-blowing factory. It was about as far away from the pomp of the Lido as one can get and still be in Venice. This being a bright, late- summer Sunday afternoon with the lagoon flooded by a warming light, it was, indeed, a typical "Olmi setting."

After welcoming his "guests" and inviting them to join him in the back of the restaurant, Olmi bypassed Lux protocol by purposely deserting the speaker's table at the front of the room to take a chair in the midst of the assembly. Then, before proper introductions could be made, he queried why the journalists had bothered to come at all: "You know my answers as well as your questions, so what's the sense of it?"

Instead, he talked in rounded phrases, musing philosophically in his Lombardy dialect about his profession, about how he seldom needed to go far from home to film a story that was "part of me," about how the only measure of a film's importance is the common denominator: man. The Story of Creation, which he had just filmed, is, in other words, "about us," not a homage to a distant deity in some picture-book.

In his quaint, casual fashion, Olmi sought to make Genesis more immediate for his listeners. Like all his masterpieces, this portion of The Bible is meant to be a personal encounter, a film carved with a storyteller's imagination, one that can enchant the hearts and minds of an audience.

At a neighbouring table sat Loredana Detto, Olmi's wife, taking it all in with the same wistful charm and glance of anchoring attention that captured the heart of the youth Domenica in Il Posto (1961), the director's early and important film. The story of a Lombard peasant boy applying for an available office job in a large Milan company, and falling shyly in love with the young secretary, Magali (Loredana Detto), the core of the film experience is a reflection on work, albeit drawn from Olmi's own recollections as an 18-year-old looking for and finding employment at the Edisonvolta company.

The Tree of the Wooden Clogs is also autobiographical, in the sense that it was drawn from stories about country people told to him by his grandfather. The Legend of a Holy Drinker is adapted from a story by Austrian writer Joseph Roth about a drunken tramp sleeping under bridges. Despite its subject, the film is a poetic, timeless statement on the soul and the need for spiritual values in a cold world, undercoated with the director's unmistakably mystical tenderness for people.

For Olmi, the "Scriptures" are pondered, handed-down oral tradition. Thus the key figure in Genesis is the old storyteller, played by Omero Antonutti, the craggy, compassionate father-figure in the films of the 
Taviani Brothers (Padre Padrone, Night of the Shooting Stars). Quite sensibly, Antonutti also plays Noah. If there is another player in the film, then it is nature itself: earth, sky, water, light. Only then come birds and animals and mankind. Adam and Eve, Cain and Abel, all the principals in Genesis save for Noah and the Storyteller, are played by the common people of Morocco. The oral tradition lives on among desert bedouins.

When Genesis premiered at Venice, Olmi and Antonutti were given a standing ovation.

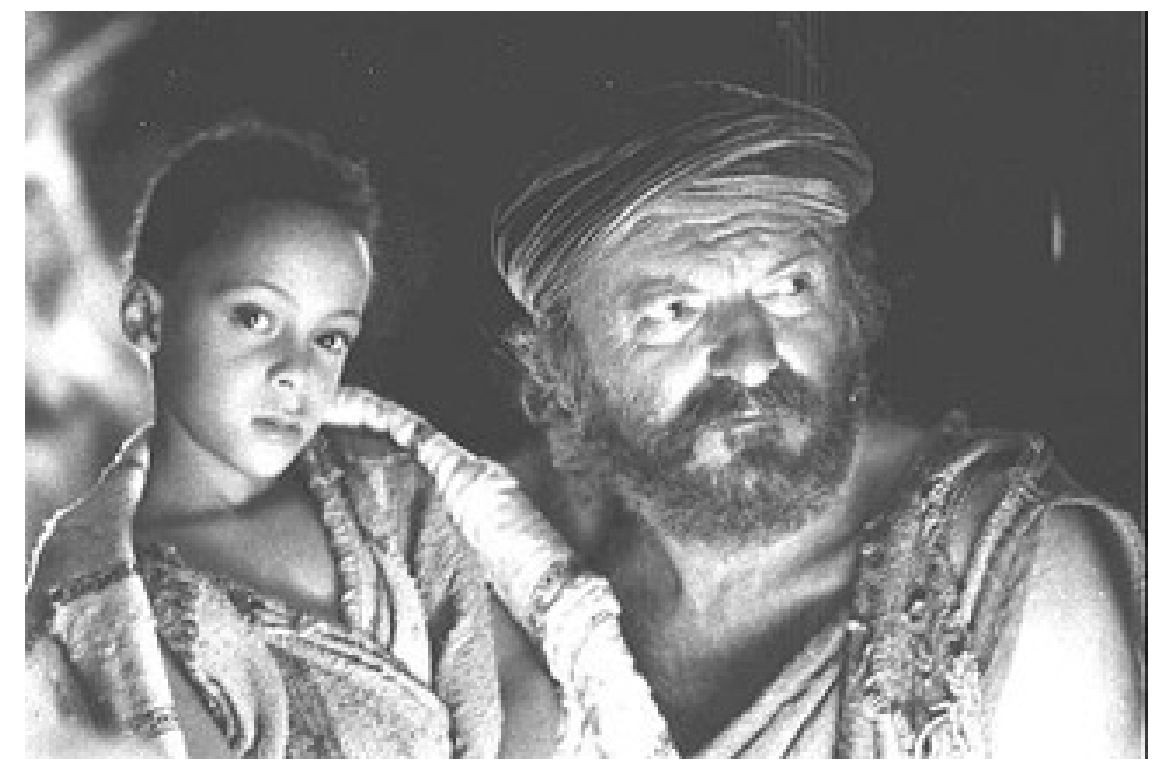

Figure 1: Genesis (dir. Ermanno Olmi, 1994)

\section{Author Information}

Ron HOLLOWAY (1933-2009) was an American critic, film historian, filmmaker and correspondent who adopted Europe as his home in the early fifties and spent much of his life in Berlin. He was an expert on the study of German cinema and against all odds produced, with his wife Dorothea, the journal German Film, keeping us up-to-date with the work of directors, producers and writers and the showing of German films around the world.

In 2007, Ron Holloway and his wife were awarded the Berlinale Camera Award. Ron also received the Bundesverdienstkreuz (German Cross of Merit), Polish Rings, Cannes Gold Medaille, the American Cinema Foundation Award, the Diploma for Support of Russian Cinema and an honorary award from the German Film Critics' Association.

Ron was also a valued contributor to Kinema for the past fifteen years. 